Izumi, Volume 8 No 1, 2019

e-ISSN: 2502-3535 p-ISSN: 2338-249X

Tersedia online di http://ejournal.undip.ac.id/index.php/izumi

\title{
STRATEGI DAGANG DAN PERMASALAHAN TOKO JEPANG DI HINDIA BELANDA SEBELUM PERANG DUNIA II
}

\author{
Stedi Wardoyo \\ Universitas Gadjah Mada \\ stedi.wardoyo@ugm.ac.id
}

\begin{abstract}
Abstrak
Awal abad ke-20 menjadi titik balik pergeseran aktivitas ekonomi orang Jepang di Hindia Belanda seiring semakin meningkatnya populasi orang Jepang di Hindia Belanda, khususnya Jawa. Pada masa ini aktivitas dagang orang Jepang yang sebelumnya didominasi oleh pedagang keliling yang menjajakan barang-barang Jepang seperti tekstil, obat-obatan, sabun, dan barang-barang kebutuhan sehari-hari lainnya hingga ke pelosok pedesaan di Jawa, bergeser menjadi aktivitas dagang secara permanen dalam bentuk toko kecil yang populer di kalangan masyarakat pada masa itu sebagai toko Jepang.

Menjelang akhir 1910 hingga awal tahun 1940-an aktivitas toko Jepang semakin berkembang dan meningkat pesat hingga menjadi salah satu ikon dalam sejarah hubungan ekonomi antara Jepang dengan Hindia Belanda. Selama kurun waktu tersebut terjadi pasang surut aktivitas dagang toko Jepang, namun pada masa krisis ekonomi dunia tahun 1920-an toko Jepang tetap mampu bertahan, bahkan pada masa itu produk-produk Jepang yang dijual toko Jepang mampu menggeser kedudukan produk-produk Cina dan Eropa (Belanda). Toko Jepang yang populer di kalangan masyarakat pribumi dikenal karena pelayanannya baik, harganya murah, dan produknya baik.

Penelitian ini mencoba melihat kembali bagaimana toko Jepang membangun jaringan dan faktor-faktor yang mendukung ataupun menghambat perkembangan toko Jepang pada masa tersebut. Dalam penelitian ini, selain catatan harian orang Jepang di Hindia Belanda seperti Jagatara Kanwa dan Nanyou no Seikatsu Kiroku, artikel surat kabar berbahasa Jepang yang terbit di Jawa yaitu Touindo Nippou juga digunakan sebagai data primer. Metode analisis isi digunakan untuk mengetahui muatan yang terkandung dalam tulisantulisan tersebut sesuai dengan tema penelitian. Kesimpulan penelitian ini adalah strategi dagang yang bertumpu pada jaringan dagang yang kuat menjadi kunci keberhasilan toko Jepang, selain faktor-faktor lain seperti keberhasilan mengobservasi kebutuhan pasar dan strategi pemasaran produknya.
\end{abstract}

Kata kunci: toko Jepang; jaringan dagang; strategi pemasaran

\begin{abstract}
(Title: Strategy Of Commerce And Issues Of Japan Shop In The Netherlands Indies Before World War II) The early of 20th century was a turning point of Japanese economic activities in Dutch East Indies, along with increasing number of Japanese population, especially in Java. In that era, Japanese trading activities that dominated by Japanese goods pitchman like textiles, drugs, soap and the other daily necessary untill suburb of Java, changed into permanent economic activities in the form of a small shop that popular among Javanese society in that era as Toko Jepang or Japanese Store.

In the end of 1910 untill early 1940s, Japanese store's activities were growing and increasing to become an icon in the economic relation between Japan and Dutch East Indies.
\end{abstract}


During that period, there was increase and decrease in Japanese store's activities, but at the world economic crisis in 1920s, Japanese Market was able to survive, even Japanese products from Japanese Store was better than Chinese and European products. Japanese store, that popular among indigenous was known for it's good service, cheap price and good quality products.

This research is trying to find how Japanese store can build it's connection and the factors that supporting and obstacling Japanese store's growth in that era. In this research, besides the diaries of Japanese immigrants such as Jagatara Kanwa and Nanyou no Seikatsu Kiroku, Japanese newspaper of Touindo Nippou was used as main sources. Content analysis was applied as a method to determine the contents in those sources which were relevant to the topic of this research. It can be concluded that the success keys of Japanese store was marketing strategies that supported by a strong trade connection, beside another factors like the success of observing people's needs and product marketing strategy.

\section{Keywords : Japanese store; marketing strategies; success}

\section{PENDAHULUAN}

Awal abad ke-20 menjadi titik balik pergeseran aktivitas ekonomi orang Jepang di Hindia Belanda seiring semakin meningkatnya populasi orang Jepang di Hindia Belanda, khususnya Jawa. Pada masa ini aktivitas dagang orang Jepang yang sebelumnya didominasi oleh pedagang keliling yang menjajakan barang-barang Jepang seperti tekstil, obatobatan, sabun, dan barang-barang kebutuhan sehari-hari lainnya hingga ke pelosok pedesaan di Jawa, bergeser menjadi aktivitas dagang secara permanen dalam bentuk toko kecil yang populer di kalangan masyarakat pada masa itu sebagai toko Jepang.

Keberadaan toko Jepang diperkirakan muncul pada tahun 1901 ketika berdiri toko Choya di Surabaya ${ }^{1}$. Menjelang akhir 1910 hingga awal tahun 1940-an aktivitas toko Jepang semakin berkembang dan meningkat pesat hingga menjadi ikon dalam sejarah hubungan ekonomi antara Jepang dengan Hindia Belanda. Selama kurun waktu tersebut terjadi pasang surut aktivitas dagang toko Jepang dan tahun 1920-1930 menjadi titik puncak kejayaan toko Jepang di Hindia

\footnotetext{
${ }^{1}$ Meta Sekar Puji Astuti, Apakah Mereka Matamata?: Orang-orang Jepang di Indonesia (18681942), Yogyakarta: Penerbit Ombak, 2008, hal. 8.
}

Belanda, meskipun pada masa yang sama terjadi krisis ekonomi dunia yang berimbas pada penurunan aktivitas perdagangan di negara-negara di seluruh dunia. Pada kurun waktu tahun 1930 - 1940 toko Jepang tetap populer dan mampu bertahan, bahkan pada masa itu produk-produk Jepang yang dijual toko Jepang mampu menggeser kedudukan produk-produk dari Cina dan Eropa, khususnya Belanda.

Kepopuleran toko Jepang, terutama di kalangan masyarakat pribumi tidak terlepas dari strategi dagang yang mereka lakukan. Salah satu strategi tersebut adalah pelayanan yang baik dan sopan, harga murah, dan produk yang dikenal berkualitas baik, selain strategi lain yang berkaitan dengan sistem manajemen internalnya. Furnivall mengemukakan bahwa kesuksesan toko Jepang merupakan perpaduan strategis bisnis antara produk bermutu dan murah, harga tetap, dan kontrol terhadap jaringan impor dan distribusi (keiretsu) ${ }^{2}$.

Setelah melalui masa berdagang keliling (gyosho), beberapa pedagang keliling orang Jepang memutuskan untuk membuka toko secara permanen dengan menjual produk-produk buatan Jepang

\footnotetext{
2 J.S Furnivall, Netherlands India: A study of Plural Economy, Cambridge: Cambridge University Press, 1939, hal.431-432
} 
mulai dari kebutuhan sehari-hari seperti sabun, keramik, obat-obatan, mainan anak, dan tekstil. Beberapa toko Jepang yang muncul pada tahun 1910-an adalah toko Nanyou (Nanyou Shoukai) milik Tsutsumibayashi Kazue di Semarang (1909), toko Ogawa milik Ogawa Rihachirou di Semarang, toko Fuji di Yogyakarta milik Sawabe Masao, dan lainlain. 3 Selama periode 1910-1920 keberadaan toko Jepang semakin berkembang dan menyebar tidak terbatas di perkotaan, namun hingga pelosok pedesaan di Jawa. Pada masa ini aktivitas perdagangan keliling masih berlangsung meskipun jumlahnya semakin berkurang.

Berdasarkan survei Konsulat Jepang di Batavia pada tahun 1914 terdapat 74 orang pemilik toko dengan pekerja sebanyak 144 orang di Jawa, dan 56 pedagang keliling yang 38 di antaranya menjual obat-obatan ${ }^{4}$. Pertumbuhan aktivitas dagang orang Jepang pada masa ini terkonsentrasi di tiga kota pelabuhan utama di Jawa yakni Surabaya, Batavia, dan Semarang. Namun demikian, keberadaan toko Jepang yang semakin berkembang pesat menjadikan kota-kota kecil di Jawa juga sebagai pasar potensial bagi mereka. Toko Nanyou yang didirikan oleh Tsutsumibayashi Kazue menjadi salah satu contoh. Hingga tahun 1927 toko Nanyou yang berpusat di Semarang berhasil memiliki 21 toko cabang dengan jumlah pekerja 127 orang Jepang yang tersebar di Batavia, Bandung, Padang, Cilacap, Purworejo, Blitar, dan kota-kota kecil lainnya ${ }^{5}$.

Salah satu kunci keberhasilan toko Jepang ini adalah strategi dagang yang bertumpu pada jaringan dagang yang kuat, selain faktor-faktor lain seperti

\footnotetext{
${ }^{3}$ Meta Sekar, op.cit. hal 114

${ }^{4}$ Murayama, Yoshitada, "Pola Penetrasi Ekonomi Jepang ke Hindia Belanda sebelum Perang”, dalam Saya Shiraishi dan Takashi Shiraishi (ed), Orang Jepang di Koloni Asia Tenggara, Jakarta: Yayasan Obor Indonesia. 1998, hal 160.

${ }^{5}$ Meta Sekar, op.cit. hal 98
}

keberhasilan mengobservasi kebutuhan pasar dan strategi pemasaran produknya. Pada masa itu mereka membentuk jaringan dagang tidak terbatas pada sesama orang Jepang yang terhimpun dalam Nihonjinkai (Perkumpulan Orang Jepang) dan Nanyou Shoukai (Perkumpulan Dagang Nanyou/Wilayah Selatan), namun juga kerja sama dengan kelompok pedagang dari etnis lain seperti Cina, Arab, dan pedagang pribumi. Namun demikian, tidak sedikit kendala yang mereka hadapi dalam upaya mengembangkan bisnis mereka di Hindia Belanda. Penurunan daya beli masyarakat akibat resesi ekonomi dunia, semakin memburuknya hubungan politik Jepang-Hindia Belanda, hingga persaingan dagang dengan produk impor lain terutama dari Cina mewarnai perjalanan toko Jepang hingga akhir masa kejayaannya seiring kebijakan invasi Jepang ke Asia tahun 1942 hingga pecah Perang Dunia II tahun 1945.

Dalam artikel ini akan dibahas tentang perkembangan dan strategi dagang toko Jepang dalam upayanya menguasai pasar Hindia Belanda, khususnya Jawa di tengah persaingan dengan pedagang Cina dan Eropa, khususnya Belanda. Selain itu permasalahan yang mereka hadapi dalam menjalankan roda bisnis hingga akhirnya keberadaan toko Jepang hilang dari bumi Nusantara seiring dengan masuknya tentara Jepang ke Hindia Belanda pada tahun 1942 juga dicoba untuk diulas. Pemaparan tentang perkembangan toko Jepang ini diharapkan dapat memberikan gambaran dan penjelasan yang ilmiah atas fakta sejarah yang terjadi di masa lampau, khususnya sejarah Indonesia pada masa kolonial. Selain itu diharapkan bisa menjadi ajang refleksi mengingat fenomena aktivitas ekonomi pada masa Indonesia kolonial ini memiliki relevansi dengan kehidupan nyata saat ini, khususnya sebagai salah satu wahana refleksi kondisi ekonomi dan perdagangan Indonesia dengan negara lain, terutama Jepang. Hal ini mengingat hingga saat ini dominasi produk-produk Jepang di 
Indonesia masih sangat kuat meskipun sedikit demi sedikit mendapat tantangan dari produk asing lain, misalnya produk Cina.

Penelitian tentang sejarah aktivitas ekonomi orang Jepang di Hindia Belanda selama ini banyak dilakukan oleh sejarawan Jepang. Namun setelah tahun 2000, beberapa peneliti sejarah dari Indonesia mulai bermunculan. Salah satunya adalah Meta Sekar Puji Astuti yang meneliti tentang sejarah perkembangan aktivitas dagang orang Jepang pada tahun 1868-1942 dikaitkan dengan pasang surut kebijakan politik luar negeri Jepang yang mengarah fasisme. Dalam bukunya 'Apakah Mereka Matamata?: Orang-orang Jepang di Indonesia (1868-1942), Astuti (2008) mencoba mengulas mengenai latar belakang migrasi orang Jepang ke Hindia Belanda dan perkembangan aktivitas ekonomi mereka hingga menjelang Perang Dunia II. Dalam Bab IV diuraikan secara lengkap tentang toko Jepang, namun secara khusus tidak dikaji tentang strategi dagang yang menjadi kunci kesuksesan toko Jepang.

Penelitian lain tentang sejarah perdagangan Hindia Belanda dengan Jepang dilakukan oleh Nawiyanto. Dalam bukunya "Matahari Terbit dan Tirai Bambu: Persaingan Dagang Jepang-Cina, Nawiyanto berusaha membandingkan persaingan dagang antara Jepang - Cina dalam situasi krisis ekonomi dunia tahun 1930-an dan 1990-an. Dalam penelitiannya, Nawiyanto berusaha menunjukkan bahwa selama krisis 1930-an dan 1990-an, Indonesia (khususnya Jawa) menjadi pasar potensial yang diperebutkan antara kepentingan perdagangan produk Jepang dan Cina, meskipun faktanya produk Cina belum mampu menggoyahkan dominasi Jepang, namun tetap menjadi ancaman serius bagi Jepang. Dalam kesimpulannya, Nawiyanto menyatakan bahwa komunitas bisnis dan jaringan distribusi menjadi kunci utama bagi kemenangan produk Jepang, meskipun faktor politis juga turut memainkan peranan yang cukup besar bagi pasang surut perkembangan perdagangan di Indonesia. Namun demikian tidak dijelaskan secara konkret tentang komunitas bisnis dan jaringan distribusi yang bagaimana yang digunakan oleh Jepang dalam mempertahankan pasar produk-produknya.

Berdasarkan kedua referensi tersebut terungkap tentang kegiatan ekonomi yang membawa kemakmuran pada kelompok-kelompok tertentu seiring perubahan ekonomi, yakni imigran Jepang di Hindia Belanda pada masa sebelum Perang Dunia II. Namun demikian ulasan khusus terkait perkembangan toko Jepang dan permasalahan yang terjadi pada masa itu belum diungkap secara mendalam dan komprehensif. Selain itu gambaran tentang strategi bisnis, khususnya berkaitan dengan pemasaran produk Jepang juga belum diulas secara mendalam. Untuk itu, artikel ini bertujuan untuk melengkapi gambaran tentang toko Jepang di Hindia Belanda, terutama Jawa pada masa sebelum Perang Dunia II.

\section{METODE}

Dalam penelitian ini, metode sejarah digunakan untuk menjawab pertanyaan-pertanyaan penelitian. Setelah proses pengumpulan sumber-sumber sejarah primer maupun sekunder berupa buku-buku, artikel, foto-foto yang berkaitan dengan kehidupan orang Jepang di Hindia Belanda pada masa sebelum Perang Dunia II, diperoleh beberapa sumber primer berupa catatan harian orang-orang Jepang yang menjalankan aktivitas ekonomi di Hindia Belanda yakni Jagatara Kanwa (Obrolan tentang Jakarta), Catatan Harian Okano Shigezo terkait kehidupannya di Hindia Belanda, Nanyou Seikatsu Kiroku (Catatan Kehidupan di Nanyou $^{6}$ ), dan sumber-sumber lain berupa

\footnotetext{
${ }^{6}$ Nanyou atau Lautan Selatan merupakan penyebutan bagi wilayah atau negara-negara tropis yang berada di sebelah selatan Jepang yakni Asia
} 
surat kabar yang terbit masa itu yakni Jawa Shinbun dan Touindo Nippou, serta dokumen-dokumen lainnya. Dari sumbersumber tersebut, melalui metode analisa isi diperoleh fakta-fakta sejarah terkait aktivitas dan perkembangan toko Jepang pada masa tersebut. Fakta-fakta tersebut untuk selanjutnya diverifikasi, diinterpretasi, dan dirangkum menjadi suatu tulisan sejarah terkait kunci sukses toko Jepang dan permasalahannya pada masa tersebut. Dengan mengetahui gambaran strategi bisnis orang Jepang pada masa lalu, diharapkan dapat menjadi referensi maupun informasi terkait model bisnis Jepang, mengingat saat ini dan masa mendatang, investasi bisnis Jepang di Indonesia menunjukkan tren semakin meningkat.

\section{HASIL DAN PEMBAHASAN \\ Perkembangan Toko Jepang dan Strategi Dagangnya. \\ Dalam aktivitas ekonomi,} khususnya terkait dengan jual beli suatu produk, pemasaran menjadi kunci utama dalam proses ini. Menurut Kotler dan Keller, pemasaran adalah suatu proses sosial yang di dalamnya individu dan kelompok mendapatkan apa yang mereka butuhkan dan inginkan dengan menciptakan, menawarkan, secara bebas mempertukarkan produk yang bernilai dengan pihak lain ${ }^{7}$. Terdapat 4 unsur utama dalam pemasaran yaitu produk, harga, tempat, dan promosi. Dalam konteks toko Jepang, keempat faktor ini yang diasumsikan menjadi kunci utama kesuksesan toko Jepang dalam memenangkan persaingan di pasar Hindia Belanda.

Tenggara dan Kepulauan Pasifik. Penyebutan ini umum dilakukan hingga Perang Dunia II

(https://kotobank.jp/word/590820)

7 Kotler dan Keller, Manajemen Pemasaran, Jakarta: Erlangga, 2009, hlm 6.
Cikal bakal toko Jepang dimulai pada awal tahun 1900-an saat beberapa pedagang keliling orang Jepang yang sebelumnya berjualan barang-barang kebutuhan sehari-hari seperti bedak, sabun, kosmetik, dan sebagainya untuk wanitawanita Jepang yang berprofesi sebagai pelacur atau karayukisan. Mereka yang sebelumnya hanya berjualan di kalangan terbatas wanita Jepang semakin lama dikenal juga di kalangan masyarakat lainnya yakni pribumi dan Eropa. Beberapa pedagang Jepang kemudian berjualan secara keliling hingga ke pelosok pedesaan di Jawa. Beberapa tokoh orang Jepang yang sukses berdagang keliling ini antara lain Ogawa Rihachirou di Tegal, Tsutsumibayashi Kazue di Semarang, Satou Shigeru di Bandung, dan Sawabe Masao di Yogyakarta.

Memasuki tahun 1910 terjadi perubahan aktivitas ekonomi orang Jepang di Hindia Belanda, khususnya Jawa dari aktivitas berdagang keliling kemudian menetap di suatu tempat dan membuka toko kecil yang pada akhirnya berkembang sebagai toko Jepang. Kepemilikan toko menjadi kegiatan ekonomi orang Jepang pada masa-masa ini. Tahun 1914 terdapat 74 pemilik toko dan 144 pekerja toko di Jawa, serta 56 pedagang keliling yang 38 di antaranya menjual obat-obatan. Kegiatan mereka terpusat di tiga kota pelabuhan utama di Jawa, yakni Batavia, Semarang, dan Surabaya. ${ }^{9}$ Kebanyakan dari pedagang keliling ini adalah anakanak muda yang datang pada awal abad ke-20 dengan tujuan mengadu nasib di Hindia Belanda atas informasi kolega atau rekan sesamanya yang terlebih dulu menjalankan aktivitas perdagangan di Hindia Belanda. Beberapa tokoh perintis toko Jepang ini di antaranya

\footnotetext{
${ }^{8}$ Yoshitada Murayama, "Pola Penetrasi Ekonomi Jepang ke Hindia Belanda sebelum Perang” dalam Saya Shiraishi dan Takashi Shiraishi (eds), Orang Jepang di Koloni Asia Tenggara, (Jakarta: Yayasan Obor Indonesia, 1998), hlm. 160.

${ }^{9}$ ibid
} 
Tsutsumibayashi Kazue pemilik toko Nanyou dan Ogawa Rihachiro pemilik toko Ogawa yang keduanya perpusat di Semarang. Gambaran tentang masa-masa awal toko Jepang disampaikan oleh Ishii Tarou, pemilik toko Jepang di Batavia sebagai berikut:

Setelah melalui masa berdagang keliling, dengan bermodal toko kecil sewaan dengan barang dagangan sedikit yang hanya satu baris dan rak dagangan satu unit, anak-anak muda yang memiliki pengalaman berdagang keliling hingga ke pelosok, memilih satu lokasi yang tepat dan memulai membuka toko yang pada akhirnya nanti mewarnai daerah-daerah di Hindia Belanda sebagai toko Jepang ${ }^{10}$.

Dalam perkembangannya,

keberadaan toko Jepang semakin dikenal dan mendapat kepercayaan dari masyarakat, terutama pribumi. Kesuksesan toko Jepang ini tidak terlepas dari upaya keras pemiliknya dalam upaya menjalankan usaha yang strategi pemasarannya benar-benar berbeda dari saat mereka berdagang keliling. Mereka buka dari pagi hari hingga larut malam dan dijaga sendiri oleh pemiliknya tanpa libur atau istirahat. Produk yang mereka jual juga semakin beragam, tidak terbatas pada produk buatan Jepang, namun juga produk Cina dan Belanda sebagaimana diceritakan oleh Ishii Tarou sebagai berikut:

Mereka menjalankan usahanya pada masa itu tanpa mengenal waktu, menjaga sendiri dan melayani pelanggan dari pagi sebelum fajar hingga larut malam. Orang-orang ini melalui kerja keras dan jatuh bangun dalam menjalankan tokonya dibandingkan saat berdagang keliling, sedikit

\footnotetext{
${ }^{10}$ Ishii Tarou, "Jawa Kusawake Monogatari” dalam Jagatara Kanwa: Ran'in Jidai Houjin no Ashiato,
} (Tokyo: Jagatara Tomo no Kai 1978), hlm. 32. demi sedikit memperoleh
kepercayaan dari pelanggan dan
pemasok barang dagangannyapun
tidak hanya importir Jepang,
namun juga pedagang Cina dan
perusahaan dagang Belanda, hingga
akhirnya semakin besar dan
berkembang ${ }^{11}$.
Dalam upaya menarik pembeli, toko-toko Jepang ini menggantungkan sebagian barang dagangannya di depan toko sehingga terlihat oleh orang-orang yang lalu lalang di depan toko dan mengundang mereka untuk datang melihatnya. Selain itu pada malam hari mereka menyalakan lampu petromaks yang sangat terang sehingga mendorong orang, dari orang Belanda, Cina, dan penduduk pribumi untuk datang dan berkumpul di sekitar toko. Dari interaksi dengan orang Jepang pemiliki toko, keberadaan toko Jepang berikut barang dagangannya semakin dikenal oleh masyarakat luas. Hal ini diceritakan oleh Ishii sebagai berikut:

Keberadaan toko Jepang di kota di daerah, saat malam hari akan terang benderang oleh lampu petromaks sehingga barang dagangan seperti mainan, tekstil, dan barang kebutuhan sehari-hari yang dipajang dengan baik terlihat berkilauan di bawah sinar lampu, dan penduduk kota atau desa itu yang melintas, dari orang terpandang hingga buruh berkumpul di sana. Orang Belanda, orang Cina, orang Indonesia dan pemilik toko yang orang Jepang juga saling berinteraksi dengan damai sehingga tempat itu serasa menjadi lokasi pengenalan produk Jepang secara damai dan alamiah. ${ }^{12}$

Salah satu hal yang menarik adalah kenyataan bahwa pada masa-masa awal berdirinya, toko Jepang juga banyak 
Izumi, Volume 8 No 1, 2019

e-ISSN: 2502-3535 p-ISSN: 2338-249X

Tersedia online di http://ejournal.undip.ac.id/index.php/izumi

mengandalkan pebisnis Cina, bahkan di Surabaya dan Batavia terbentuk kemitraan bisnis Jepang-Cina dengan tujuan utama meningkatkan hubungan dagang bagi keuntungan kedua komunitas bisnis. ${ }^{13}$

Hingga tahun 1920 toko Jepang mengalami pertumbuhan pesat tidak terbatas pada jumlah, namun juga jenis produk yang diperdagangkan. Jika pada masa perdagangan keliling produk obatobatan mendominasi penjualan, setelah tahun 1914 bergeser menjadi barang kebutuhan sehari-hari/kelontong. Hal ini tidak terlepas dari peningkatan pesat impor barang-barang Jepang ke Hindia Belanda selama Perang Dunia I akibat terhentinya pasokan barang dari Eropa sebagai dampak dari perang tersebut. Kondisi ini juga mendorong beberapa pemilik toko Jepang seperti Kazue Tsutsubayashi beralih menjadi pengimpor. ${ }^{14}$ Kondisi ini juga mendorong toko-toko Jepang untuk memperluas pasar dengan mendirikan cabang-cabangnya di kota-kota lain hingga kota-kota kecil di daerah sehingga terbentuk jaringan distribusi produk Jepang di Hindia Belanda.

Salah satu contoh jaringan toko Jepang adalah Nanyou Shoukai milik Tsutsumibayashi Kazue yang berpusat di Semarang. Nanyou Shoukai merupakan salah satu contoh gambaran perubahan aktivitas dagang orang Jepang di Hindia Belanda dan salah satu yang dianggap sukses melebarkan sayapnya. Hingga tahun 1918 Nanyou Shoukai memiliki 24 cabang yang tersebar di Solo, Yogyakarta, Batavia, Surabaya hingga kota-kota kecil di Jawa, terutama wilayah Jawa Tengah ${ }^{15}$.

\footnotetext{
${ }^{13}$ Peter Post, "Karakteristik Kewirausahaan Jepang dalam Ekonomi Indonesia sebelum Perang" dalam J. Thomas Lindblad (ed.), Fondasi Historis

Ekonomi Indonesia (Yogyakarta: Pustaka Pelajar, 2002), hlm. 356

${ }^{14}$ Yano Toru, Nanshin no Keifu, (Tokyo:

Chuuookooronsha, 1975), hlm. 97

${ }^{15}$ Aoki Sumio, Indonesia di Mata Masyarakat

Jepang di Hindia Belanda 100 Tahun yang Lalu

dalam Kartu Pos Bergambar Foto, (Jakarta: Bina

Komunika Asiatama, 2017), hlm 189
}

Nanyou Shoukai bergerak dalam bisnis toko kelontong dan obat-obatan dengan nilai penjualan mencapat 164 ribu yen ${ }^{16}$.

Tsutsumibayashi Kazue lahir di kota Shinjo, Yamagata pada tanggal 26 Desember 1973, satu-satu anak lelaki dari 5 bersaudara. Ayahnya sebenarnya termasuk bekas samurai yang jatuh miskin akibat kebijakan pemerintah Meiji menghapus golongan samurai dan melarang aktivitas mereka. Dua tahun setelah putus Sekolah Dasar akibat ketidakmampuan biaya, Tsutsumibayashi bekerja berturut-turut sebagai guru tidak tetap di desa Shimizu selama dua tahun lalu menjadi sipir penjara di Yamagata. Ketika berusia 23 tahun, Tsutsumibayashi pergi ke Taiwan yang saat itu menjadi koloni Jepang setelah menang dalam perang Jepang-Cina. Kemampuannya berbahasa Cina dialek Fukien membawa dia memperoleh kepercayaan seorang pedagang yang bisnisnya menyebar hingga ke Singapura, Hongkong, dan Jawa bernama Kakushun sebagai kepala konsultan hukum perusahaan Kakushun. Tahun 1902 Tsutsumibayashi memisahkan diri dari perusahaan Kakushun dan mendirikan toko kelontong dan pakaian di Taipei.

Tahun 1907 Tsutsumibayashi kembali ke Jepang untuk mendalami halhal yang bersifat religi hingga akhirnya tahun 1908 dia memutuskan untuk memeluk agama Kristen Protestan. Hal ini mengakibatkan perubahan pemikiran terkait kehidupannya yakni berbuat sesuatu untuk bangsanya, khususnya membantu para pemuda dalam mengembangkan jiwa dan semangat mereka ${ }^{17}$. Hal ini juga dilatarabelakangi adanya keprihatinan Tsutsumibayashi terhadap banyaknya pemuda yang kebingungan dan mengurungkan niatnya untuk merantau ke luar negeri akibat maraknya aksi penolakan terhadap imigran Jepang di Amerika. Tsutsumibayashi ingin mengajak

\footnotetext{
${ }^{16}$ ibid

${ }^{17}$ Yano Toru, hlm 92
} 
para pemuda tersebut untuk merantau ke wilayah Nanyou dan menjalankan aktivitas perdagangan di sana. Bekerja sama dengan pendeta Uemura Masahisa, Tsutsumibayashi memilih 15 orang pemuda dari sekitar 200 pemuda yang mendaftar untuk dilatih teknik-teknik berdagang keliling dan bertahan hidup di wilayah Nanyou ${ }^{18}$.

$$
\text { Pada bulan April } 1909
$$

Tsutsumibayashi dan kelimabelas pemuda tersebut mengawali perjalanan menuju Semarang di Pulau Jawa dari pelabuhan Yokohama. Mereka tiba di Semarang pada 30 Mei 1909 dan mengawali aktivitas dengan membuka toko kelontong di sebuah rumah sederhana yang disewa dan berdagang keliling. Toko ini diberikan nama Nanyou Shoukai (toko Nanyou) yang menjual barang kebutuhan sehari-hari, khususnya obat-obatan dan tekstil. Dalam menjalankan usahanya, Tsutsumibayashi bertindak sebagai manajer yang mengatur aktivitas dagang kelima belas pemuda tersebut. Mereka hidup sangat sederhana dan mengikuti aturan-aturan secara ketat di antaranya:

1. Bangun tidur pukul 06.00 dan beribadah setelah makan malam pukul 19.00

2. Buka toko pukul 07.00 dan tutup pukul 21.00 dengan waktu istirahat siang pukul 13.30

3. Aktivitas dagang keliling dimulai pukul 08.30 hingga 18.00

4. Dalam urusan pekerjaan, perintah atasan/senior harus dihormati dan diikuti.

5. Dalam urusan di luar pekerjaan, hubungan persaudaraan dilandasi tanpa melihat senioritas.

6. Kepercayaan terhadap rekan dan saudara seiman dalam satu gereja adalah hal yang terbaik.

7. Sekali dalam setiap bulan diadakan pertemuan rutin untuk bertukar pikiran dan membahas

tentang perkembangan usaha.
8. Meditasi bersama untuk memperbaiki psikis dan meningkatkan keimanan.

9. Dengan alasan apapun tidak seorangpun diizinkan keluar/meninggalkan wilayah Nanyou selain untuk kembali ke Tokyo ${ }^{19}$.

Dengan aturan-aturan yang ketat dan dilandasi ajaran Kristen yang kuat, Tsutsumibayashi menjalankan Nanyou Shoukai secara idealis meskipun dalam perjalanannya menemui beberapa kendala seperti penolakan atau ketidaksanggupan beberapa pemuda yang bekerja bersamanya. Namun demikian dengan strategi tersebut, Nanyou Shoukai semakin berkembang dan sukses dengan sembilan kantor cabang pada awal 1912.

Salah satu kunci kesuksesan Nanyou Shoukai terkait dengan produk yang dipasarkannya adalah kemampuannya membangun jaringan, baik dalam pasokan maupun distribusinya. Beberapa produk yang dipasarkan seperti permen menthol dan obat oles untuk sakit kepala sangat diminat masyarakat dan mendominasi penjualan. Produk-produk tersebut merupakan produk buatan Prefektur Yamagata yang diimpor secara langsung dan seakan dimonopoli oleh Nanyou Shoukai ${ }^{20}$. Dalam catatan hariannya, Kushindan, Tsutsumibayashi menyusun langkah-langkah dan tahapantahapan pengembangan Nanyou Shoukai yang terdiri atas:

1. Masa berdagang keliling sebagai awal berdiri dan mencari pengalaman.

2. Masa berdagang eceran menggunakan kemampuan diri dan finansial secara bersama-sama.

3. Perdagangan ekspor impor sebagai penerapan pengetahuan dan kemampuan finansial.

4. Kemandirian masing-masing unit usaha berbasis manajemen yang kuat dan usaha lahan

\footnotetext{
${ }^{19}$ Ibid. hlm 94-95

${ }^{20}$ Ibid. hlm 95
} 
perkebunan.

5. Bisnis yang berlandaskan idealisme ${ }^{21}$ Melalui tahapan-tahapan tersebut, awal tahun 1912 hingga 1919 Nanyou Shoukai semakin berkembang dan berhasil membangun jaringan yang terdiri atas 38 unit toko Nanyou yang tersebar di Hindia Belanda. Selain itu didirikan juga unit usaha yang bergerak dalam bidang ekspor impor antara Jepang dan Hindia Belanda.

Pada tahun 1914 diselenggarakan pameran dagang di Semarang yang diikuti 273 pedagang Jepang. Dalam kesempatan tersebut Tsutsumibayashi memperoleh penghargaan emas untuk produk unggulan yang dipamerkan yakni produk mint dan minyak mint. Pada tahun 1918 dalam peringatan 10 tahun berdirinya Nanyou Shoukai, Tsutsumibayashi membagikan buku saku yang berisi kisah perjalanan dan suka duka selama membangun Nanyou Shoukai serta medali peringatan kepada seluruh relasinya ${ }^{22}$. Hal ini menunjukkan bahwa keberadaan Nanyou Shoukai tidak dapat dipandang sebelah mata dan perusahaan ini memainkan peranan yang cukup penting dalam aktivitas perekonomian di Hindia Belanda.

\section{Permasalahan Toko Jepang}

Keberadaan toko Jepang yang semakin marak di seluruh Nusantara membawa dampak postif bagi konsumen, khususnya masyarakat pribumi karena mereka mempunyai alternatif dalam memenuhi kebutuhan sehari-hari seperti obat-obatan, sabun, hingga pakaian. Pecahnya Perang Dunia I tahun 1914 membawa dampak pada peningkatan impor barang-barang Jepang ke Hindia Belanda akibat terhentinya pasokan barang dari Eropa. Kondisi ini juga mendorong pergeseran aktivitas beberapa toko Jepang yang sebelumnya melayani penjualan retail menjadi importir umum sebagaimana terjadi pada Nanyou Shoukai.

\footnotetext{
${ }^{21}$ Ibid. hlm. 96

${ }^{22}$ Aoki Sumio, hlm. 191
}

Setelah berakhir Perang Dunia I tahun 1918, hubungan dagang antara Jepang dan Hindia Belanda mengalami peningkatan pesat. Di dalam negeri Jepang pada saat yang sama telah dilakukan reformasi industri tahap kedua yang berhasil meningkatkan kapasitas produksi sehingga mendorong ekspor ke luar negeri. Tujuan utama ekspor Jepang yang sebelumnya lebih terfokus kepada negaranegara Eropa, akibat melemahnya perekonomian negara-negara Eropa dan terganggunya transportasi dari dan ke Eropa akibat perang, membuat Jepang mengalihkan tujuan ekspornya ke negaranegara Asia seperti Hindia Belanda yang memiliki pasar potensial dan sangat besar. Porsi Jepang dalam perdagangan luar negeri Hindia Belanda mengalami peningkatan pesat dari 1,6 persen pada tahun 1913 menjadi 10,9 persen pada tahun 1929 dan di tahun 1934 meningkat tajam menjadi 31,8 persen $^{23}$. Dalam perdagangan produk tekstil, impor dari Jepang ke Hindia Belanda menempati posisi pertama dengan porsi sebesar 79 persen pada tahun $1926^{24}$. Faktor lain yang mendukung peningkatan jumlah produk Jepang ke Hindia Belanda adalah kemudahan transportasi setelah dibukanya jalur pelayaran langsung yang menghubungkan kota-kota pelabuhan di Jepang seperti Osaka, Kobe dan Yokohama dengan Jawa. Selain peningkatan volume perdagangan, efisiensi pengangkutan barang menyebabkan harga produk Jepang juga mengalami penurunan.

Setelah Perang Dunia I berakhir, terjadi krisis ekonomi dunia tahun 1929 yang juga berimbas pada perekonomian Hindia Belanda. Kondisi ini juga berimbas pada toko Jepang di Hindia Belanda. Selain pulihnya pasokan barang dari Eropa, kebijakan devaluasi yang dilakukan pemerintah Jepang tahun 1927

\footnotetext{
${ }^{23}$ J.S Furnivall. "Netherlands India, A Study of Plural Economy" (Cambridge: Cambridge AT University Press, 1939), hlm 431

${ }^{24}$ ibid
} 
menyebabkan harga produk Jepang semakin mengalami penurunan. Di sisi lain hal ini menguntungkan konsumen, namun mengakibatkan penurunan keuntungan yang diperoleh Toko Jepang. Salah satu toko Jepang, Kawai Shoten yang memiliki dua cabang dan berpusat di Mojokerto melaporkan bahwa penjualan mereka mengalami kenaikan 20 persen, namun keuntungan yang diperoleh menurun hingga 40 persen $^{25}$. Dalam menghadapi situasi ini, beberapa jaringan toko Jepang seperti Fuji Yoko milik Masao Sawabe yang berpusat Yogyakarta mengambil langkah strategis dengan mengalihkan penjualan produk yang sebelumnya banyak ditujukan kepada konsumen kelas atas warga Belanda dan asing lainnya, kepada konsumen kelas bawah yakni warga pribumi dalam jumlah besar meskipun keuntungannya rendah. Selain itu mereka membangun rute distribusi yang berjangkauan luas untuk membanjiri pasar Hindia Belanda yang terpukul akibat krisis dengan produk Jepang ${ }^{26}$. Pada tahun 1932 , sebagai akibat penurunan nilai mata uang yen, varian produk Jepang yang membanjiri pasar Hindia Belanda juga semakin banyak tidak terbatas pada produk tekstil, kosmetik, dan obat-obatan, namun juga semen, kaca, sepeda hingga ban mobil. Dapat dikatakan bahwa tidak ada produk Amerika dan Eropa yang tidak dapat disaingi oleh produk Jepang 27.

Permasalahan lain yang terjadi yang menjadi sorotan dan kritikan keras masyarakat Hindia Belanda terkait produk Jepang adalah penurunan kualitas produk yang dijual toko Jepang akibat besarnya permintaan sehingga proses produksi dan impor dilakukan tanpa memperhatikan kualitas. Dalam salah satu artikel Jawa Nippou tanggal 1 Januari 1922 dituliskan tentang kasus produk mainan untuk acara

\footnotetext{
${ }^{25}$ Murayama, "Pola Penetrasi Ekonomi Jepang ke

Hindia Belanda sebelum Perang”, hlm 162

${ }^{26}$ Ibid. hlm 164

${ }^{27}$ J.S Furnivall, hlm 432
}

Natal benar-benar kualitasnya tidak sebagaimana yang dijual sebelum Perang Dunia $\mathrm{I}^{28}$. Masalah lain terkait produk adalah surat jaminan untuk sebuah produk parfum dan kosmetik yang diimpor dari Osaka yang dinilai palsu. Hal ini dianggap salah satu penipuan konsumen mengingat tidak ada jaminan bahwa produk yang dijual tersebut adalah benar-benar produk resmi atau asli ${ }^{29}$.

Demikianlah beberapa permasalahan yang menyertai tingginya angka penjualan produk Jepang di Hindia Belanda pada masa tersebut. Selain faktor internal yang berkaitan dengan mutu produk, pemasaran, dsb, memasuki tahun 1930-an toko Jepang juga dihadapkan pada permasalahan eksternal, khususnya perubahan situasi politik internasional yang membawa dampak sangat signifikan terhadap perkembangan toko Jepang di Hindia Belanda.

\section{Masalah Perdagangan dan Dampaknya bagi Masyarakat Jepang}

Memasuki tahun 1930 merupakan awal masa-masa sulit bagi toko Jepang. Khususnya bagi pedagang Cina yang telah lama mapan, keberadaan toko Jepang merupakan saingan yang berat dibandingkan dengan pedagang Eropa ataupun pribumi ${ }^{30}$. Menghadapi persaingan ini, para pedagang Cina menyikapinya secara beragam, namun sebagian besar pedagang memperlihatkan sikap permusuhan dan menyerukan gerakan boikot produk Jepang ${ }^{31}$. Invasi Jepang ke Manchuria tahun 1931 mengakibatkan gerakan anti-produk Jepang di kalangan orang Cina semakin berkembang ke arah radikalisme. Aksi teror, perusakan toko

\footnotetext{
${ }^{28}$ Jawa Nippou, 1 Januari 1922

${ }^{29}$ Jawa Nippou, 5 Juni 1923

${ }^{30}$ Nawiyanto, "Matahari Terbit dan Tirai Bambu:

Persaingan Dagang Jepang-Cina", Yogyakarta:

Ombak, 2010, hlm 61

${ }^{31}$ Ibid. hlm 63
} 
Izumi, Volume 8 No 1, 2019

e-ISSN: 2502-3535 p-ISSN: 2338-249X

Tersedia online di http://ejournal.undip.ac.id/index.php/izumi

Jepang, hingga seruan untuk menutup paksa toko-toko kecil yang menjual produk Jepang berkembang di seluruh wilayah Jawa $^{32}$. Menghadapi masalah pemboikotan ini, masyarakat Jepang sendiri menerapkan langkah-langkah defensif dengan mengandalkan kebijakan pemerintah Hindia Belanda ${ }^{33}$. Di sisi lain, pemerintah Hindia Belanda mengambil tindakan dengan menekan aksi anti-Jepang tersebut dengan pertimbangan bahwa gerakan tersebut dikhawatirkan dapat mengacaukan pranata sosial dan politik di Hindia Belanda, selain pertimbangan ekonomi bahwa suplai barang Jepang dengan harga murah dipandang mampu menstabilkan perekonomian Hindia Belanda ${ }^{34}$.

Hingga pertengahan dekade 1930an, pemerintah Hindia Belanda pada dasarnya masih bersikap bersahabat terhadap masyarakat Jepang di Hindia Belanda, meskipun timbul kecurigaan terhadap derasnya arus masuk barang dan manusia dari Jepang ke Hindia Belanda sejak krisis ekonomi dunia. Selain itu, perubahan kebijakan politik luar negeri Jepang yang diwarnai dengan gerakan militer dan invasi ke wilayah selatan, serta keluarnya Jepang dari Liga Bangsa-Bangsa menyebabkan mereka semakin mewaspadai aktivitas orang Jepang di Hindia Belanda. Namun hingga tahun 1936, sebagaimana dinyatakan dalam buku Laporan Pemerintah Hindia Belanda bahwa masyarakat Jepang di Hindia Belanda terdiri atas imigran yang rajin dan tidak banyak tingkah sehingga kepolisian tidak pernah dibuat pusing oleh mereka karena mereka tidak pernah berhubungan dengan aktivitas-aktivitas subversi atau spionase $^{35}$.

Memasuki akhir 1936, terjadi perubahan besar dalam hubungan Jepang

\footnotetext{
${ }^{32}$ Ibid. hlm 64

${ }^{33}$ Gotou Ken'ichi, “Jepang dan Pergerakan

Kebangsaan Indonesia”, Jakarta: Yayasan Obor Indonesia, 1998, hlm 189

34 ibid

${ }^{35}$ Ibid. hlm 192
}

dan Hindia Belanda. Pada tahun 1936 Jepang menyatakan keluar dari kesepakatan London dan Washington yang berisi tentang Perjanjian Pengurangan Persenjataan Angkatan Laut, disusul dengan pernyataan Jepang terkait kebijakan ekspansi ke Selatan sebagai Haluan Kebijakan Negara. Hal ini menyebabkan pemerintah Hindia Belanda semakin mewaspadai langkah-langkah Jepang dan meningkatkan pengawasan terhadap orang-orang Jepang di Hindia Belanda. Kondisi ini diperburuk setelah pecahnya perang Jepang-Tiongkok tahun 1937 yang memunculkan gerakan-gerakan yang mengarah pada anti Jepang yang dilakukan oleh masyarakat Belanda maupun Cina. Di beberapa kota, seperti Bandung terjadi aksi pengeroyokan terhadap beberapa pemilik toko Jepang oleh sekelompok pemuda Belanda ${ }^{36}$. Selain itu terjadi insiden-insiden kecil seperti pelemparan batu kepada anak-anak Jepang yang berangkat ke sekolah, penghalangan terhadap pembeli toko Jepang, hingga pelemparan toko Jepang dengan cat dan kotoran manusia ${ }^{37}$. Untuk pertama kali, situasi seperti ini membawa dampak besar terhadap aktivitas orangorang Jepang di Hindia Belanda. Orangorang Jepang di Hindia Belanda yang sebelumnya secara politis tidak pernah terikat dengan negaranya, untuk pertama kali harus menanggung tekanan akibat kebijakan negaranya. Menghadapi situasi yang tidak menguntungkan ini, satusatunya tindakan mereka adalah bertindak defensif dan berharap pada keberhasilan perundingan perdagangan antara Jepang dan Hindia Belanda. Di sisi lain, situasi ini juga mendorong kesadaran nasionalisme sebagai orang Jepang, khususnya di kalangan pemuda.

Memasuki tahun 1940, situasi politik di Eropa semakin memanas sejak

\footnotetext{
${ }^{36}$ Ibid. hlm 219

${ }^{37}$ Saya Shiraishi dan Takashi Shiraishi, “ Orang Jepang di Koloni Asia Tenggara”, Jakarta: Yayasan Obor Indonesia, 1998, hlm 28.
} 
serangan Jerman ke Polandia yang menyulut peperangan dalam skala lebih besar. Tanggal 10 Mei 1940, pemerintah Belanda terpaksa mengungsi ke London, Inggris akibat invasi Jerman. Keadaan ini menyebabkan pemerintah Hindia Belanda semakin waspada akibat Jepang memiliki aliansi dengan Jerman. Suasana anti Jepang semakin meningkat sehingga posisi orang Jepang yang tinggal di Hindia Belanda juga semakin rentan dan terpojok. Dalam situasi yang demikian, Perundingan Perdagangan II menjadi harapan satusatunya untuk menyelamatkan kehidupan mereka. Hal ini termuat dalam salah satu artikel Touindo Nippou tanggal 20 Agustus 1940 sebagai berikut:

Perasaan kita saat ini dapat dikatakan hanya dengan satu kata yakni harapan. Semoga saudara kita bangsa Belanda bersama-sama dengan kita menaruh harapan pada hasil perundingan antara kedua negara Jepang dan Belanda ${ }^{38}$.

Namun harapan tersebut berakhir sia-sia. Saat dibuka pada bulan September 1940 perundingan berjalan alot akibat sikap anti-Jepang dari pemerintah Belanda, selain tuntutan pihak Jepang yang dianggap melampaui batas yakni permintaan suplai minyak dan besi baja dari Hindia Belanda ke Jepang. Akibat kegagalan perundingan perdagangan ini, hubungan diplomatik antara Jepang dan Hindia Belanda semakin memburuk. Pada tanggal 15 Februari 1941 pemerintah Hindia Belanda mengeluarkan kebijakan mencabut perlakuan bebas visa bagi orang Jepang yang diikuti kebijakan pembatasan barang dan orang dari Jepang ke Indonesia serta pembekuan aset orang Jepang di Hindia Belanda pada tanggal 28 Juli 1941 menjadi pukulan akhir bagi masyarakat Jepang di Hindia Belanda ${ }^{39}$. Tahun 1941 hingga pecah Perang Dunia II terjadi

\footnotetext{
${ }^{38}$ Ibid. hlm 218

${ }^{39}$ Ibid. hlm 223
}

eksodus warga Jepang keluar dari Hindia Belanda untuk kembali ke tanah airnya. Mereka menjual dengan harga murah atau meninggalkan begitu saja aset yang telah dibangunnya dengan penuh perjuangan selama beberapa dasawarsa. Hal ini sekaligus menandai masa berakhirnya toko Jepang di Hindia Belanda.

\section{SIMPULAN}

Perjalanan panjang toko Jepang di Hindia Belanda diwarnai dengan beragam cerita, baik suka maupun duka bagi pemiliknya. Pasang surut perjalanan toko Jepang tidak dapat dilepaskan dari faktor internal maupun eksternal yang menyertainya. Pada masa-masa awal perintisannya tahun 1900 hingga 1920, sebagian besar toko Jepang dibangun oleh pemiliknya yang telah teruji melalui pengalaman mereka menjalani perdagangan keliling. Perpaduan antara keuletan, pelayanan, dan kemampuan mengenali kebutuhan konsumen menjadi salah satu kunci perkembangan toko Jepang. Selain itu, strategi manajemen melalui sistem jejaring atau keiretsu dan pemasaran melalui penetapan harga pas dan potongan harga (obral) juga memainkan peranan penting dalam proses pengembangan toko Jepang. Hal ini yang membuat toko Jepang berbeda dengan toko-toko lain, khususnya toko Cina di Hindia Belanda pada masa itu.

Pada kurun waktu 1920 hingga 1936 dapat dikatakan sebagai masa keemasan toko Jepang. Selain keberhasilan membangun sistem jejaring internal sendiri, perkembangan pesat sistem transportasi pelayaran dari Jepang ke Hindia Belanda dan sebaliknya, serta berkembangnya jalur pengangkutan di Jawa menyebabkan kemudahan bagi proses distribusi barang dagangan. Hal ini berdampak pada efisiensi biaya pengangkutan sehingga harga jual produk dapat ditekan. Faktor lain yang mendukung masa kejayaan ini adalah terhentinya pasokan barang dari Eropa sebagai akibat perang, sehingga 
Izumi, Volume 8 No 1, 2019

e-ISSN: 2502-3535 p-ISSN: 2338-249X

Tersedia online di http://ejournal.undip.ac.id/index.php/izumi

beberapa toko Jepang seperti Nanyou Shoukai juga bertindak sebagai importir produk Jepang. Besarnya pangsa pasar Hindia Belanda dan beragamnya kebutuhan masyarakatnya mendorong peningkatan nilai impor produk Jepang meskipun pada saat yang sama terjadi krisis ekonomi dunia.

Namun setelah tahun 1936, perkembangan toko Jepang menunjukkan penurunan seiring perubahan politik dalam negeri Jepang. Implementasi paham invasi ke Selatan (Nanshinron) yang mulanya diserukan Angkatan Laut Jepang dengan tujuan mencari sumber alam, khususnya minyak bumi yang sangat dibutuhkan Jepang menjadi pangkal permasalahan yang berimbas pada memburuknya hubungan diplomatik Jepang dan Hindia Belanda. Hal ini menjadi pukulan telak yang mengakibatkan runtuhnya kejayaan toko Jepang di Hindia Belanda, sekaligus menjadi penanda masa akhir pendudukan Belanda dan dimulainya babak baru pendudukan Jepang di Indonesia.

\section{DAFTAR PUSTAKA}

\section{Artikel, Buku, Makalah, dan Laporan}

Aoki, Sumio. (2017). Indonesia di Mata Masyarakat Jepang di Hindia Belanda 100 Tahun yang Lalu dalam Kartu Pos Bergambar Foto. Jakarta: The Daily Jakarta Shinbun.

Astuti, Meta Sekar Puji. (2008). Apakah Mereka Mata-mata?: Orang-orang Jepang di Indonesia (1968-1942). Yogyakarta: Penerbit Ombak.

Furnivall, J.S. (2017). Netherlands India: A Study of Plural Economy. Cambridge: Cambridge University Press. 1939

Gotou, Ken'ichi. (1998). Jepang dan Pergerakan Kebangsaan Indonesia. Jakarta: Yayasan Obor Indonesia.
Kotler dan Keller. (2009). Manajemen Pemasaran. Jilid I. Edisi ke 13. Jakarta: Erlangga,

Murayama, Yoshitada. (1998). Pola Penetrasi Ekonomi Jepang ke Hindia Belanda sebelum Perang dalam Shiraishi Saya dan Shiraishi Takashi. Orang Jepang di Koloni Asia Tenggara. Jakarta: Yayasan Obor Indonesia.

Nakamura, Takashi. (1979). Batabia-jou Nisshi I-III. Tokyo: Touyou Bunkou.

Nawiyanto. (2010). Matahari Terbit dan Tirai Bambu: Persaingan Dagang Jepang-Cina. Yogyakarta: Penerbit Ombak.

Okano, Shigezo. (1942). Nanyou no Seikatsu Kiroku. Tokyo: Nishikijou.

Post, Peter. (2002). Karakteristik Kewirausahaan Jepang dalam Ekonomi Indonesia sebelum Perang dalam J. Thomas Lindblad. Fondasi Historis Ekonomi Indonesia. Yogyakarta: Pustaka Pelajar.

Post, Peter dan Touwen-Bouwsma, Elly. (1997). Japan, Indonesia and The War: Myths and Realities. Leiden: KITLV Press.

Ricklefs, M.C. (2001). A History of Modern Indonesia since c.1200. California: Stanford University Press.

Shiraishi, Saya dan Shiraishi, Takashi. (1998). Orang Jepang di Koloni Asia Tenggara. Jakarta: Yayasan Obor Indonesia.

Shouwaki Nihon to Indoneshia. (1986). Tokyo: Keisoshobo.

Takeda, Shigesaburou (ed). (1978). Jagatara Kanwa: Ran In Jidai Houjin no Ashiato. tanpa penerbit. 
Izumi, Volume 8 No 1, 2019

e-ISSN: 2502-3535 p-ISSN: 2338-249X

Tersedia online di http://ejournal.undip.ac.id/index.php/izumi

Tokutei Kenkyuu "Bunka Masatsu".

Yano, Toru. (1975). Nanshin no Keifu. Tokyo: Chuuookooronsha.

(1978).Kondo Sadaaki shi Intabyuu Kiroku.

Van Zanden, Jan Luiten dan Daan Marks. (2014). Ekonomi Indonesia 18002010: Antara Drama dan Keajaiban Pertumbuhan. Jakarta: Penerbit Kompas.

\section{Surat Kabar}

Touindo Nippou, 1 Januari 1922

Touindo Nippou, 5 Juni 1923 